\title{
Moderators of telework effects on the work-family conflict and on worker performance
}

Moderators of telework effects

\author{
Escuela de Administración de Empresas, Instituto Tecnológico de Costa Rica, \\ Cartago, Costa Rica
}

\begin{abstract}
Purpose - The relations telework-work interference with the family (WIF), telework-family interference with work (FIW), and telework-performance have been widely studied; however, results of different investigations are contradictory. This may be related to third variables that moderate the effect of relations. The purpose of this paper is to analyze the moderating effect of worker responsibilities outside of the work environment on telework-FIW and telework-WIF relations, as well as the moderating effect of control by the supervisor on teleworkers in the telework-performance relation.

Design/methodology/approach - A total of 92 teleworkers were interviewed, and 72 non-teleworkers who work in four public institutions. Non-teleworkers work in the same departments as teleworkers, and carry out similar functions. In addition, 33 supervisors were interviewed who evaluated performance of both groups. Hierarchical lineal regression analysis models were used to evaluate the influence of telework on the dependent variables.

Findings - The results obtained reveal that where there are low-responsibility levels, teleworkers present a lower FIW than non-teleworkers; however, with high levels of responsibility, teleworkers show higher FIW. Additionally, supervisors' control of teleworkers was found to have a negative effect on their pro-activity and adaptability to tasks.

Originality/value - The findings provide new empirical evidence about the effect of moderating variables in the relation between telework-work-family conflict and telework-performance. Besides the results provide practical and useful implications to organizations that implement telework programs.
\end{abstract}

Keywords Performance, Telework, Work-family conflict, Teleworkers, Moderator variables

Paper type Research paper

\section{Introduction}

Several studies have investigated the effects of telework on family-work relations, and on work performance, but in spite of this, the effects of telework are not clear, given that results of the different studies are contradictory. For instance, some researchers emphasize the benefits telework has on work-family balance (Hill et al., 2003; Allen, 2001; Gajendran and Harrison, 2007), while others encounter opposite results (Ordoñez 2012; Kossek et al., 2006, Vittersø et al., 2003; Lapierre and Allen, 2006). The findings of studies about the effect of telework on worker performance also show diverse results. Golden and Veiga (2008), Harker Martin and MacDonnell (2012), Dutcher (2012) and Mekonnen (2013) found that the telework tends to increase worker performance, while Kossek et al. (2006) and Golden et al. (2008) did not find a significant relation between telework and worker performance. Gajendran

\section{JEL Classification - M15}

(C) Martín Solís. Published in the European Journal of Management and Business Economics. Published by Emerald Publishing Limited. This article is published under the Creative Commons Attribution (CC BY 4.0) licence. Anyone may reproduce, distribute, translate and create derivative works of this article (for both commercial and non-commercial purposes), subject to full attribution to the original publication and authors. The full terms of this licence may be seen at http://creative commons.org/licences/by/4.0/legalcode

The author would like to acknowledge the support from Instituto Tecnológico de Costa Rica, Vicerrectoría de Investigación. This research was supported and funded by Instituto Tecnológico de Costa Rica.

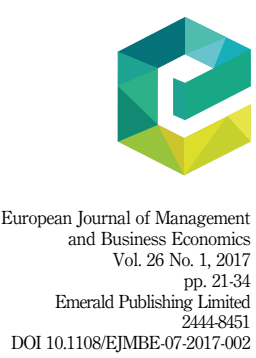

Received 2 October 2016 Revised 13 February 2017 Accepted 27 February 2017 
EJMBE 26,1

and Harrison (2007) even carried out a meta-analysis of 38 investigations, and did not find positive effects of telework on worker performance. At the same time, O'Neill et al. (2009), and Grant et al. (2013) warn of different psychological and environmental factors that can have a negative effect on productivity when work is carried out at a distance.

The discrepancies found between results of various studies may be based on different variables that eventually moderate telework effects (Sullivan, 2012). For this reason, some researchers emphasize the need to have information about the circumstances that lead telework to have positive effects for teleworkers, and which circumstances lead telework to have negative effects on different response variables (Madsen, 2011; Sullivan, 2012; Shockley and Allen, 2007).

Given the discrepancy of results and the need carry out in-depth studies of this situation, the present study is intended to analyze the moderating effect of responsibilities of individuals outside of the work environment on the relation between telework and work-family and family-work conflicts. This analysis was previously addressed by Shockley and Allen (2007), but their study was focused only on women, and they did not use a control group to compare telework effects, which is done in this investigation.

I will also analyze whether control of teleworkers by supervisors moderates the relation between telework and performance. Some authors have indicated that methods based on control must be set aside for telework to be more effective (Wiesenfeld et al., 1999; Pyöriä, 2011); however, the present study will assess this empirically.

\section{Interaction between responsibility and telework on work-family conflict}

Persons tend to perceive telework as a factor that facilitates child care and organization of household chores (Hilbrecht et al., 2008; Ammons and Markham, 2004; Crosbie and Moore, 2004). These perceptions can be supported by the results of scientific analysis. Some research indicates that the telework has a positive effect on the work-family balance (Hill et al., 2003; Allen, 2001; Gajendran and Harrison, 2007), because it has the potential to provide autonomy and flexibility for persons to carry out leisure activities and fulfill their family duties. Evidence obtained by Baruch (2000) showed that teleworkers experience less stress because they are better able to tend to urgent family affairs. In addition, persons gain free time that they can invest in family and household chores, given that they save commuting time from their home to their office (Baruch, 2000; Noonan et al., 2007). DuBrin (1991) observes that work satisfaction may be increased when persons have flexibility for dealing with household and family responsibilities.

The level of responsibilities individuals have in their home may have an influence on telework effects. Shockley and Allen (2007) showed that when persons have more family responsibilities, space and time flexibility generates positive results on the family-work balance, but when there is a low level of responsibility, the results are negative. According to the authors, it is possible that persons with greater responsibilities have experienced high levels of conflict between work and family, and telework helps them get reorganized, but those with a low level of responsibility tend to become disorganized. Consistent with these findings, Madsen (2011) mentions several studies in which it was determined that persons with children report stress reduction thanks to telework. This may be associated with the fact that telework facilitates handling household chores and child care (Sullivan and Smithson, 2007). Given that some authors have indicated a positive impact of telework on work-family balance because it provides flexibility for organizing family and personal responsibilities with work responsibilities, and the evidence of Shockley and Allen (2007) in this regard, the following hypotheses are proposed:

H1a. Teleworkers with greater responsibilities outside of the work environment are able to reduce family interference with work (FIW).

H1b. Teleworkers with greater responsibilities outside of the work environment are able to reduce work interference with the family (WIF). 
Interaction between control by supervisors and telework on work performance Favorable job attitudes like commitment (Harker Martin and MacDonnell, 2012; Desrosiers, 2001) and motivation (Hill et al., 2003) are exchanged in reciprocity for a more flexible work arrangements. These attitudes can promote positive outcomes as individual competence, pro-activity and adaptability to changes in the tasks. However, if the supervisors do not give autonomy enough to work independently or does not trust in its employees and they are controlling its actions, it could not diminish the positive attitudes and performance. The job autonomy is an determinant of pro-activity outcomes (Frese et al., 1996) and make the people more receptive to change because they feel more able to control the work outcomes (Parker and Sprigg, 1999). Besides, supervisor trusting on employee promotes behaviors beyond the formal expectative and productivity (Deluga, 1994; Atuahene-Gima and Li, 2002; Nyhan, 2000). Desrosiers (2001) have found that it is important the employee feels organizational support when they telework, because it promotes positive outcomes. Therefore, the autonomy, trust and support that the supervisor give to teleworks can influence the effect of telework on performance.

Additionally, Dahlstrom (2013) states that democratic and non-authoritarian leadership focused on relations rather than on tasks is required, because telework success depends on communication, confidence and support provided by supervisors. Consistent with this, Wiesenfeld et al. (1999) pointed out that methods of control for worker supervision may be dysfunctional for teleworkers. At the same time Pyöriä (2011) and Golden (2009) indicated that supervisors must set aside traditional control-based management and focus more on results-based management for telework to function. This conclusion is supported by Mello (2007), who states that the adequate functioning of telework depends on a supervisor feeling comfortable delegating responsibilities for the entire work unit and allowing employee discretion with respect to the way he or she completes work assignments. On their part, Kowalski and Swanson (2005), and Dimitrova (2003), agree that the level of control exerted by supervisors is a determining factor for telework success. Malhotra et al. (2007) even mention that one of the most common reasons for failures of telework programs is the perception of directors that employees must be constantly supervised to assure that they are always busy. In addition, Sullivan (2012) states that one of the challenges for telework to continue growing is changing supervisors' fear of losing control of their workers if they cannot oversee them visually.

Since different authors support the point of view that telework requires supervisors who trust their workers and set aside control-based management, the present paper analyze if the supervisors control on teleworkers moderates the relation between telework and three variables that Griffin et al. (2007) use for measuring worker individual performance such as task proficiency, task pro-activity and individual adaptability to tasks. Thus the following hypothesis are proposed:

H2a. Telework has a positive effect on individual workers' task proficiency when supervisors control work of their subordinates less strictly.

H2b. Telework has a positive effect on individual task pro-activity (ITPA) when supervisors control work of their subordinates less strictly.

H2c. Telework has a positive effect on individual adaptability to tasks when supervisors control work of their subordinates less strictly.

\section{Methodology}

Sample and procedure

A letter was sent to the chiefs of telecommuting program of ten public institutions, in order to find the institutions interested to participate in the study. The letter clarified the
Moderators of telework effects 
EJMBE 26,1

objectives of the study and invited the chiefs at a meeting to explain the details. Only four institutions showed interest and provided contact information of their telecommuters and not teleworkers who performed similar functions.

A total of 92 teleworkers were interviewed, and 72 non-teleworkers who performed functions similar to those of the teleworkers. The information was collected in September and October 2014. The 50 percent of the sample was composed by men, and the average age was 40.13 years. In addition, 33 supervisors were interviewed who evaluated performance of both groups.

The group of teleworkers is composed by individuals with a variety of professions (e.g. Lawyers, Business managers, Psychologists, Agronomists, etc.) who work in four public Costa Rican institutions, while the non-teleworkers group made up by individuals who work in the same unit or department of the teleworkers. In addition, the non-teleworkers had similar tasks to their teleworking co-workers; this allows work-family conflict and performance to be compared between groups.

A self-administered questionnaire was applied to teleworkers and non-teleworkers with questions about aspects related to work-family conflict, sociodemographic characteristics, and other aspects related to the way in which they teleworked (for instance, amount of days, control by supervisor, schedule flexibility, etc.). A self-administered questionnaire was applied to supervisors of teleworkers and non-teleworkers to evaluate worker performance during the last month.

An invitation with a link to the questionnaire was sent to participants, via electronic mail. Eight days later a reminder was sent to those who had not responded. If after four reminders they had not responded, they were contacted on the telephone to apply the questionnaire directly, or to coordinate an appointment at their place of work, so that they could answer the questionnaire in a self-administered manner.

\section{Measures}

Family-work conflict. This variable was measured using eight items of Gutek et al. (1991). Four items measure WIF (for instance, "I am worried about my work during my free time"), and four items measure FIW (for instance, "My personal duties are so numerous that they keep me away from my work"). The response scale used for these items had four values: very frequently, frequently, seldom, or never. Cronbach's $\alpha$ for WIF was 0.83 , and for FIW was 0.76 .

Performance. Griffin et al. (2007) created and validated a new model of work role performance based on three dimensions: individual task behaviors, team member behaviors and organization member behaviors. Each one of these dimensions has three sub-dimensions. According to the authors, each sub-dimension may be used as an independent scale. This investigation uses the three sub-dimensions of individual task behaviors. These are as follows.

Individual task proficiency (ITP). This describes task fulfillment behaviors and the role assigned to a worker. It was measured with three items of Griffin et al. (2007) plus an additional item which was included to give strength to the construct "Completes tasks or chores in the allotted time." The response scale has a range of 1-5, where 5 represents the most positive rating. The value of Cronbach's $\alpha$ was 0.92 .

ITPA. This describes whether a worker has the initiative to propose and look for better ways to carry out his or her tasks. It is also measured with three items. The response scale has a range of $1-5$, where 5 represents the most positive rating. The value of Cronbach's $\alpha$ was 0.87 .

Individual adaptability to tasks (ITA). This describes whether a worker responds correctly to changes in his or her tasks. It is measured with three items. The response scale has a range of 1-5, where 5 represents the most positive rating. The value of Cronbach's $\alpha$ was 0.89 . 
Telework (TEL). Teleworkers were assigned the code 1 and non-teleworkers were assigned the code 0 .

Control (CTR). The code 1 was assigned to those cases when teleworkers perceived that their supervisor was constantly or occasionally monitoring (high control) them during their work, and code 0 if they perceived that their supervisor almost did not monitor them while they teleworked, or not monitored them at all (low control).

Responsibility (RE). An indicator was constructed to measure the level of responsibility individuals have outside the work environment, based on the following items:

- has children younger than 13 ;

- must carry out chores related to care of some relative or loved one due to old age, disease or another reason;

- is currently studying (for a high school diploma, or for a bachelors, masters or other degree); and

- percentage of household chores he or she carries out at home (cooking, washing, cleaning, ironing, etc.).

The three first items were coded with a 1 if the person was living the indicated situation and 0 if he or she was not living that situation. The fourth item was coded between 1 and 0 , where 0 corresponded to an individual who carried out 0 percent of household chores, and 1 corresponded to a person who carried out 100 percent of his or her household chores. The indicator was constructed by averaging the score obtained in the four items and then multiplying it by 100 . Scores therefore range between 0 and 100 , where 100 is the highest level of responsibility.

Control variables. Four variables are controlled for, which could confuse the effect of independent variables on dependent variables. They are: gender (where woman $=1$ and man $=0$ ), age (current age), time in months of working under the current supervisor (T.SUP), time in months of working in the institution (T.INS), institution for which he or she works (PJ: The Judicial Branch, PROCU: Attorney General's Office, FITO: Plant Protection Services of the Ministry of Agriculture and Livestock Breeding, and CNFL: the National Power and Light Company.

\section{Data analysis}

Hierarchical lineal regression analysis models were used to evaluate the influence of telework on the dependent variables, following Baron and Kenny (1986) method. Thus, in the first step the control variables was added, then in a second step the variables with direct effects, and finally the moderator variable (Baron and Kenny, 1986). Compliance with the assumption of homoscedasticity was evaluated for each model, using the Breusch-Pagan test at 10 percent significance. In models that used WIF, FIW and ITPA as dependent variables, the null hypothesis of Breusch-Pagan test was not rejected, so the homocedasticity assumption is approved. When ITP and ITA are the dependent variables, the assumption of homocedasticity is not met. In these cases, Huber and White Robust-Error calculation was applied to the models, as stands Freedman (2012). Data analysis was performed on the software R.

\section{Results}

Table I presents the averages, standard deviations, and correlations among the variables studied. Table II presents the results of the hierarchical regression model with which $\mathrm{H1a}$ and $H 1 b$ are evaluated. It is important to mention that the variable responsibility was standardized to prove the moderating effect, as suggested by Cohen et al. (2003). The data

Moderators of telework effects 
EJMBE

26,1

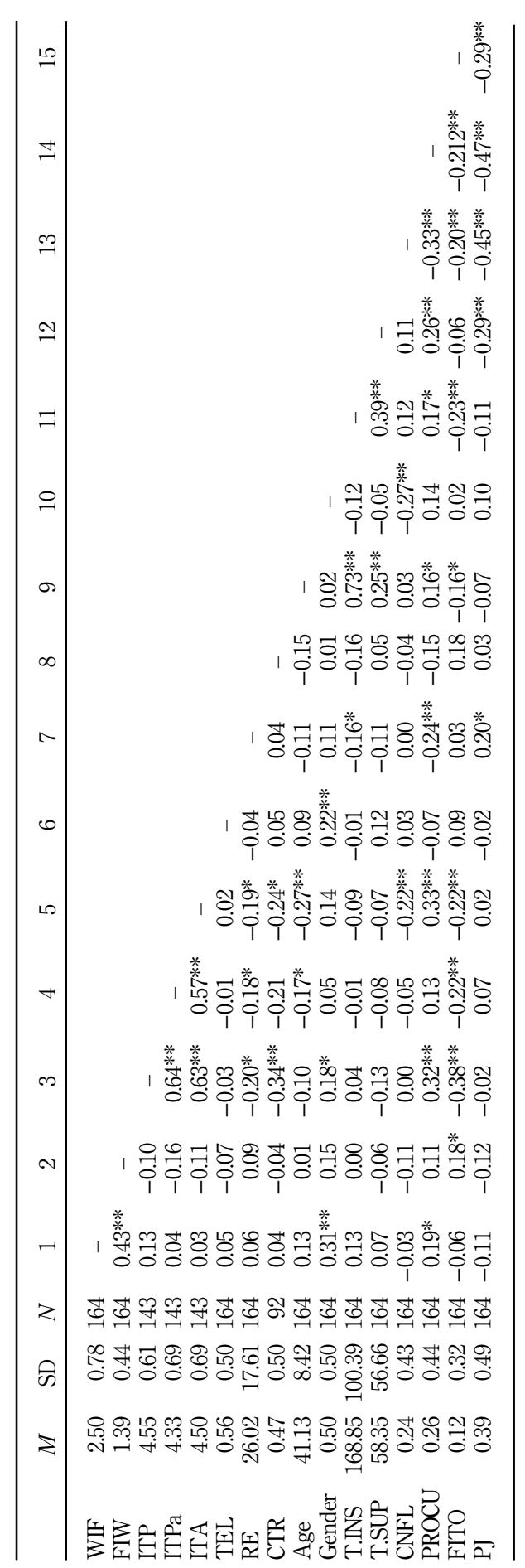

Table I.

Means, standard deviations, total sample and intercorrelations 


\begin{tabular}{|c|c|c|c|c|c|c|c|}
\hline Variable & Model 1 & $\begin{array}{c}\text { WIF } \\
\text { Model } 2 \\
\end{array}$ & Model 3 & Model 1 & $\begin{array}{c}\text { FIW } \\
\text { Model } 2\end{array}$ & Model 3 & $\begin{array}{l}\text { Moderators } \\
\text { of telework }\end{array}$ \\
\hline \multicolumn{8}{|l|}{ Step 1} \\
\hline Age & 0.01 & 0.01 & -0.01 & -0.03 & -0.02 & -0.05 & \multirow{7}{*}{27} \\
\hline Gender & $0.33^{* *}$ & $0.32 * *$ & $0.33^{* *}$ & 0.14 & 0.15 & $0.18^{*}$ & \\
\hline T.SUP & 0.13 & 0.14 & 0.15 & 0.10 & 0.10 & 0.11 & \\
\hline T.INS & -0.02 & -0.02 & -0.01 & -0.11 & -0.10 & -0.08 & \\
\hline CNFL & 0.11 & 0.12 & 0.11 & 0.03 & 0.05 & 0.03 & \\
\hline PROCU & 0.17 & $0.20 *$ & 0.16 & 0.16 & 0.18 & 0.10 & \\
\hline FITO & 0.03 & 0.03 & 0.02 & $0.23^{* *}$ & $0.24 * *$ & $0.21^{*}$ & \\
\hline \multicolumn{8}{|l|}{ Step 2} \\
\hline Telework (TEL) & & 0.00 & -0.01 & & -0.10 & -0.12 & \\
\hline Responsibility (RE) & & 0.09 & -0.06 & & 0.11 & -0.23 & \\
\hline \multicolumn{8}{|l|}{ Step 3} \\
\hline TEL $\times$ RE & & & 0.18 & & & $0.38 * *$ & \\
\hline$R^{2}$ & 0.15 & 0.15 & 0.16 & 0.08 & 0.10 & 0.14 & \\
\hline Adjusted $R^{2}$ & 0.11 & 0.10 & 0.11 & 0.04 & 0.05 & 0.09 & \\
\hline$F$ & $3.80^{* * *}$ & $3.09 * *$ & $2.98 * *$ & 1.99 & 1.97 & $2.66^{* *}$ & Table II. \\
\hline $\mathrm{df}$ & 156 & 154 & 153 & 156 & 154 & 153 & Hierarchical \\
\hline \multicolumn{7}{|c|}{ Notes: Values represent standardized coefficients. ${ }^{*} p<0.05 ; * * p<0.10$} & for WIF and FIW \\
\hline
\end{tabular}

obtained from these first models show that the telework variable does not have a significant effect on WIF and FIW; it is, however, shown that the effect of telework on FIW changes according to the level or responsibility individuals have outside of the work environment $(B=0.19, p<0.05)$. As can be seen in Figure 1, telework helps reduce FIW when the level or responsibility is low, however, when the level of responsibility is high, teleworkers show a higher level of FIW.

Table III presents the results of testing $\mathrm{H} 2 \mathrm{a}-\mathrm{H} 2 \mathrm{c}$. Data were divided into two groups to apply the models. The first group consists of teleworkers who responded that they were monitored constantly or occasionally by their supervisors during their work, and their co-workers who do not telework, which makes up the control group. The second group consists of teleworkers who responded that they were not monitored or monitored only occasionally by their supervisors while they worked, and their co-workers who did not telework.

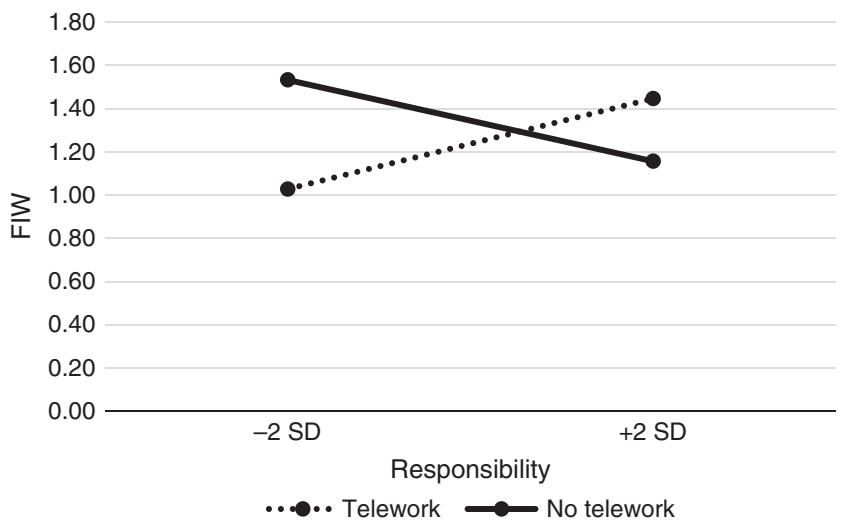

Figure 1. Moderating effect of responsibility on family interference work 
EJMBE

26,1

28
Table III.

Hierarchical regression analysis for ITP, ITP and ITA, according to control level

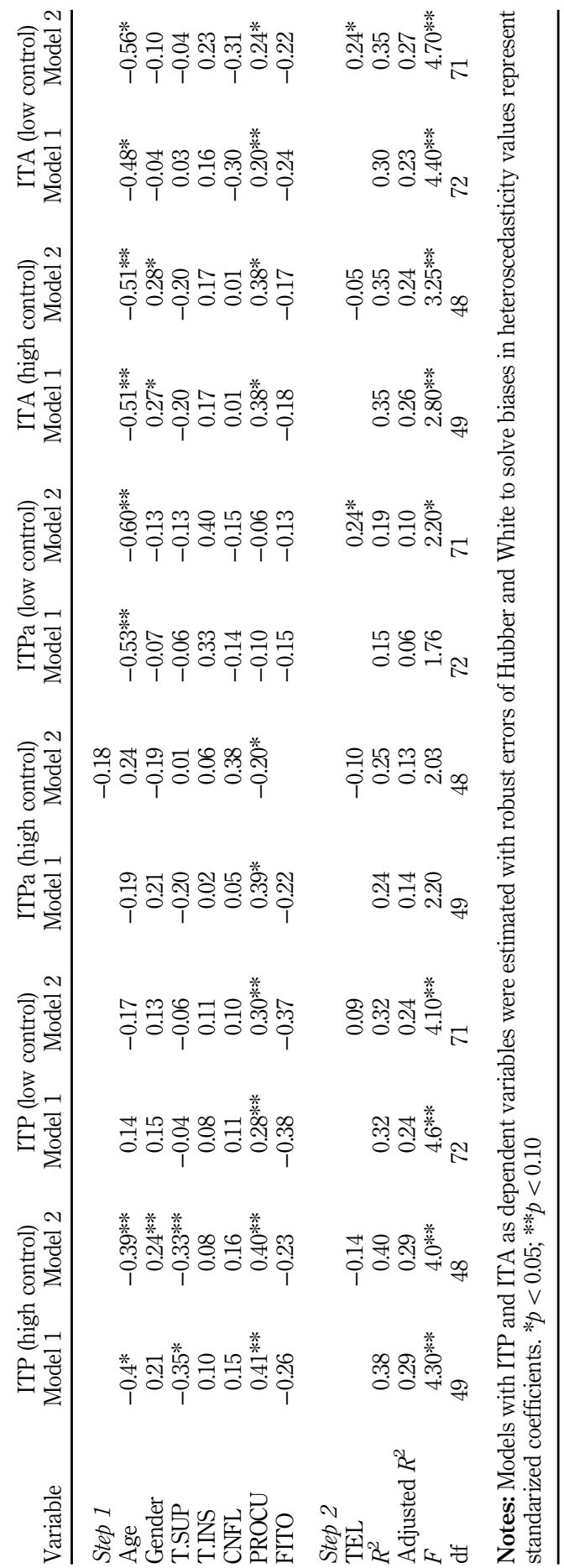


Hierarchical regressions are applied to each group, which explain the telework effect on the three performance variables analyzed. The results support $H 1 b$, given that the group of teleworkers who are not monitored or monitored only occasionally by their supervisors show greater pro-activity than the control group $(B=0.24, p<0.05)$, while teleworkers who are monitored more by their supervisors do not show significant differences with respect to the control group $(B=-0.10, p>0.05)$. $H 2 b$ is also supported because teleworkers who are monitored only occasionally or not at all, show significant differences in terms of adaptability to tasks compared to individuals in the control group $(B=0.24, p<0.05)$.

Differences regarding individual proficiency are not found between those who telework and those who do not, both for those who are highly monitored $(B=-0.14, p>0.05)$ and for those who are not monitored $(B=0.09, p>0.05)$.

\section{Discussion and conclusions}

Given the differences found in the results of several investigations about the impact of telework on work-family balance and worker performance, the present study analyzed two possible variables that could moderate those relations. Specifically, it proposed that the level of responsibility individuals have outside of the work environment moderates telework-FIW and telework-WIF relations. The study also analyzed if the level of control over teleworkers exercised by supervisors affected the relation between telework and individual performance.

Regarding the first hypotheses, the results obtained showed that teleworkers with a higher level of responsibilities have a higher FIW, contrary to H1a and findings by Shockley and Allen (2007). According to them, telework provides flexibility for organizing family and personal responsibilities with work responsibilities, however, teleworkers participating in this study do not have the flexibility to carry out their tasks on a schedule defined by themselves (77 percent indicate having little or no flexibility for teleworking on their own schedules). They are therefore prevented from taking care of non-work activities at the time that is most convenient for them, just as those who work at their office. It may even be possible that being at home brings about more conflicts because many times relatives or friends do not understand that the individual is not available to take care of other matters (Kossek et al., 2006).

To evaluate $H 2 a-H 2 c$, the relations between telework and three individual performance variables proposed by Griffin et al. (2007) were analyzed: individual proficiency, pro-activity and adaptability to tasks. These relations were evaluated in two groups. The first consists of teleworkers who are monitored frequently or occasionally by their supervisors, and the corresponding non-teleworkers who carry out similar functions as teleworkers. The second group consists of teleworkers who are almost not monitored or not monitored at all by their supervisors, and non-teleworkers who make up the control group.

The results obtained do not support the hypothesis proposed concerning the individual proficiency variable $(H 2 a)$. Of the three performance measurements, this is the most similar to measurements used in other studies of telework (Golden and Veiga, 2008; Hurd, 2010; O'Neill et al., 2009; Kossek et al., 2006), because also assesses adequate compliance with rules and formal tasks. Based on these types of measurements, Gajendran and Harrison (2007) had already proposed that after 20 years of telework research, data about its influence on worker effectiveness were not conclusive. Sometimes the research shows positive influence and sometimes not. This situation may be related to the type of task carried out by the individuals studied. According to Dutcher (2012), telework has a positive impact on performance in creative tasks, but this is not the case in tasks that require little creativity.

With respect to pro-activity, the $H 2 a$ proposed is supported, given that teleworkers who are more monitored do not show significant differences with respect to non-teleworkers, while teleworkers with a low-control level show a greater pro-activity
Moderators of telework effects 
EJMBE 26,1

than non-teleworkers. There is evidence indicating positive effects of worker autonomy and trust from supervisors on variables that are closely related to pro-activity, such as entrepreneurship and innovation (Moon, 1999; Denti and Hemlin, 2012; Bakovic et al., 2013). Therefore, it is not surprising that individuals that have flexibility to work from their homes, and are trusted by their supervisors, are sufficiently empowered to become more pro-active in their work.

With respect to adaptability to their tasks, $H 2 c$ is supported, given that teleworkers with low control showed significant adaptability differences as compared to the non-teleworker group, while teleworkers with high control did not show differences in terms of adaptability. Telework implies substantial changes for workers; for this reason it is expected that those who telework will develop a greater capacity to adapt to other organizational changes. However, if supervisors are constantly monitoring their work, this may reduce teleworkers' interest in adapting, or otherwise limit the possibility that workers learn to confront new situations independently.

\section{Practical implications}

Workers and organizations should be aware of the responsibility degree that possible teleworkers possess outside the workplace, especially if telecommuting mode will not allow the flexibility to work in the schedule of convenience. For this reason, organizations must establish mechanisms to evaluate the living conditions of the worker before including it in the modality of telecommuting. In that sense it is important to investigate the responsibilities of the subject in the home, if he or she is in charge of caring for other people, for example, children or older adults, and of course if it coursing some kind of study. These variables can largely define the burden of responsibilities that subjects have.

If a subject has broad responsibilities, the organization and the subject should define together possible strategies to prevent FIW. Two strategies that can help are: the evaluation and strengthening of the individual time management ability (Kossek et al., 2006; Osnowitz, 2005), and the appropriation and legitimation of a quiet space to work in the home (Fonner and Stache, 2012). Thus, if the subject has a large load and few skills to manage the time, it may require some type of training on time management, before sending it to telework. Besides, if the subject does not have an adequate space conditions at home for teleworking, may require a conditioning of their workspace. Take possession of a space in the home to work could help reduce the interruptions of their personal responsibilities in the life, partly due to the fact that one of the main symbols used by persons to separate the work and the family environments is physical space (Fonner and Stache, 2012).

Telework programs must also train supervisors to set aside traditional control-based management. Piskurich (1998) points out that supervisors and workers spend an excessive amount of time reviewing what they are doing at home, instead of focusing on reviewing completed work. Supervisors should thus focus on developing worker evaluation mechanisms based on objectives and goals, so that what is monitored is the quality of completed products and compliance with deadlines. Although supervisors must set aside control, they cannot lose sight of the need for communication, given that this is an equally necessary mechanism for telework to function properly (Pyöriä, 2011; Mello, 2007). Given this situation, it is also important that the organization has identified those supervisors who are more controllers, because if they are to take charge teleworkers can harm them in terms of pro-activity and adaptability. As mentioned above, these supervisory styles should be made aware of the negative effect that can generate on the worker.

The trust that must be shown in teleworkers cannot be disregarded either, so that they can act with flexibility while they telework, which may lead to higher levels of pro-activity and adaptability to changes. In this way a constant communication should be maintained but focused on coordinating and not controlling. 
Limitations and future research areas

It is important to highlight that the sample for the study is mostly made up by individuals who telework for short periods of time (the average time of teleworking of individuals in the sample of the study is 1.9 days of a total of 5 work days in a week). It is therefore relevant to verify if the effects found are replicated or change in populations that telework more intensively.

To analyze telework effects with greater methodological rigor, it is necessary to create an experimental design. However, this is not always possible with the topic of telework. If a quasi-experiment is carried out, it would be useful to have response variable measurements before the individual starts teleworking. This was not possible in the present investigation because the individuals had already been teleworking for some time when evaluations were carried out - on average; they had teleworked for 22.6 months.

Another limitation is that the number of individuals in the experimental group is larger than that in the control group, because in some departments where more than one individual was teleworking, there was a smaller number of non-teleworkers who performed functions similar to those of teleworkers. In spite of this limiting factor, it was assured that every teleworker had a counterpart properly representing the counterfactual.

This study analyzed the impact of control by supervisors, but there are several variables related to the management style of supervisors, which may also influence telework effects, and they must be analyzed in further investigations. These include communication between supervisor and worker, transactional leadership exercised by supervisors, and empathy between supervisor and worker.

With respect to the impact of responsibility on telework, it is necessary to analyze triple interactions arising from combining telework-responsibility, time management ability,or, telework-responsibility and possible methods to separate family chores and work duties.

\section{References}

Allen, T.D. (2001), "Family-supportive work environments: the role of organizational perceptions", Journal of Vocational Behavior, Vol. 58 No. 2, pp. 414-435.

Ammons, S.K. and Markham, W.T. (2004), "Working at home: experiences of skilled white collar workers”, Sociological Spectrum, Vol. 24 No. 2, pp. 191-238.

Atuahene-Gima, K. and Li, H. (2002), "When does trust matter? Antecedents and contingent effects of supervisee trust on performance in selling new products in China and the United States", Journal of Marketing, Vol. 66 No. 3, pp. 61-81.

Bakovic, T., Lazibat, T. and Sutic, I. (2013), "Radical innovation culture in croatian manufacturing industry", Journal of Enterprising Communities: People and Places in the Global Economy, Vol. 7 No. 1 , pp. $74-80$.

Baron, R.M. and Kenny, D.A. (1986), "The moderator-mediator variable distinction in social psychological research: conceptual, strategic, and statistical considerations", Journal of Personality and Social Psychology, Vol. 51 No. 6, pp. 1173-1182.

Baruch, Y. (2000), "Teleworking: benefits and pitfalls as perceived by professionals and managers", New Technology, Work and Employment, Vol. 15 No. 1, pp. 34-49.

Cohen, J., Cohen, P., West, S.G. and Aiken, L.S. (2003), Applied Multiple Correlation/Regression Analysis for the Behavioral Sciences, Erlbaum, Mahwah, NJ.

Crosbie, T. and Moore, J. (2004), "Work-life balance and working from home", Social Policy and Society, Vol. 3 No. 3, pp. 223-233.

Dahlstrom, T.R. (2013), "Telecommuting and leadership style", Public Personnel Management, Vol. 42 No. 3, pp. $438-451$.
Moderators

of telework effects 
EJMBE 26,1

Deluga, R.J. (1994), "Supervisor trust building, leader-member exchange and organizational citizenship behavior", Journal of Occupational and Organizational Psychology, Vol. 67 No. 4, pp. 315-326.

Denti, L. and Hemlin, S. (2012), "Leadership and innovation in organizations: a systematic review of factors that mediate or moderate the relationship", International Journal of Innovation Management, Vol. 16 No. 3, pp. 1-20.

Desrosiers, E.I. (2001), "Telework and work attitudes: the relationship between telecommuting and employee job satisfaction, organizational commitment, perceived organizational support, and perceived co-worker support", doctoral dissertation, Purdue University, West Lafayette, IN.

Dimitrova, D. (2003), "Controlling teleworkers: supervision and flexibility revisited”, New Technology, Work and Employment, Vol. 18 No. 3, pp. 181-195.

DuBrin, A.J. (1991), "Comparison of the job satisfaction and productivity of telecommuters versus in-house employees: a research note on work in progress", Psychological Reports, Vol. 68 No. 3c, pp. 1223-1234.

Dutcher, E.G. (2012), "The effects of telecommuting on productivity: an experimental examination the role of dull and creative tasks", Journal of Economic Behavior \& Organization, Vol. 84 No. 1, pp. 355-363.

Fonner, K.L. and Stache, L.C. (2012), "All in a day's work, at home: teleworkers management of micro role transitions and the work-home boundary", New Technology, Work and Employment, Vol. 27 No. 3, pp. 242-257.

Freedman, D. (2012), "On the so-called 'Huber sandwich estimator' and 'robust' standard errors", The American Statistician, Vol. 60 No. 4, pp. 299-302.

Frese, M., Kring, W., Soose, A. and Zempel, J. (1996), "Personal initiative at work: differences between East and West Germany", Academy of Management Journal, Vol. 39 No. 1, pp. 37-63.

Gajendran, R.S. and Harrison, D.A. (2007), "The good, the bad, and the unknown about telecommuting: meta-analysis of psychological mediators and individual consequences", Journal of Applied Psychology, Vol. 92 No. 6, pp. 1524-1541.

Golden, T.D. (2009), "Applying technology to work: toward a better understanding of telework", Organization Management Journal, Vol. 6 No. 4, pp. 241-250.

Golden, T.D. and Veiga, J.F. (2008), "The impact of superior-subordinate relationships on the commitment, job satisfaction, and performance of virtual workers", The Leadership Quarterly, Vol. 19 No. 1, pp. 77-88.

Golden, T.D., Veiga, J.F. and Dino, R.N. (2008), "The impact of professional isolation on teleworker job performance and turnover intentions: does time spent teleworking, interacting face-to-face, or having access to communication-enhancing technology matter?", Journal of Applied Psychology, Vol. 93 No. 6, pp. 1412-1421.

Grant, C.A., Wallace, L.M. and Spurgeon, P.C. (2013), "An exploration of the psychological factors affecting remote e-worker's job effectiveness, well-being and work-life balance”, Employee Relations, Vol. 35 No. 5, pp. 527-546.

Griffin, M.A., Neal, A. and Parker, S.K. (2007), "A new model of work role performance: positive behavior in uncertain and interdependent contexts", Academy of Management Journal, Vol. 50 No. 2, pp. 327-347.

Gutek, B.A., Searle, S. and Klepa, L. (1991), "Rational versus gender role explanations for work-family conflict”, Journal of Applied Psychology, Vol. 76 No. 4, pp. 560-568.

Harker Martin, B. and MacDonnell, R. (2012), "Is telework effective for organizations? A meta-analysis of empirical research on perceptions of telework and organizational outcomes", Management Research Review, Vol. 35 No. 7, pp. 602-616.

Hilbrecht, M., Shaw, S.M., Johnson, L.C. and Andrey, J. (2008), "I'm home for the kids: contradictory implications for work-life balance of teleworking Mothers", Gender, Work \& Organization, Vol. 15 No. 5, pp. 454-476. 
Hill, E.J., Ferris, M. and Märtinson, V. (2003), "Does it matter where you work? A comparison of how three work venues (traditional office, virtual office, and home office) influence aspects of work and personal/family life", Journal of Vocational Behavior, Vol. 63 No. 2, pp. 220-241.

Hurd, D.A. (2010), "Comparing teleworker performance, satisfaction, and retention in the joint interoperability test command", doctoral dissertation, NorthCentral University, San Diego, CA.

Kossek, E.E., Lautsch, B.A. and Eaton, S.C. (2006), "Telecommuting, control, and boundary management: correlates of policy use and practice, job control, and work-family effectiveness", Journal of Vocational Behavior, Vol. 68 No. 2, pp. 347-367.

Kowalski, K.B. and Swanson, J.A. (2005), "Critical success factors in developing teleworking programs”, Benchmarking: An International Journal, Vol. 12 No. 3, pp. 236-249.

Lapierre, L.M. and Allen, T.D. (2006), "Work-supportive family, family-supportive supervision, use of organizational benefits, and problem-focused coping: implications for work-family conflict and employee well-being", Journal of Occupational Health Psychology, Vol. 11 No. 2, pp. 169-181.

Madsen, S.R. (2011), "The benefits, challenges, and implications of teleworking: a literature review", Culture \& Religion Journal, Vol. 1 No. 3, pp. 148-158.

Malhotra, A., Majchrzak, A. and Rosen, B. (2007), "Leading virtual teams", The Academy of Management Perspectives, Vol. 21 No. 1, pp. 60-70.

Mekonnen, T. (2013), "Examining the effect of teleworking on employees' job performance", doctoral dissertation, Walden University, Minneapolis, MN.

Mello, J.A. (2007), "Managing telework programs effectively", Employee Responsibilities and Rights Journal, Vol. 19 No. 4, pp. 247-261.

Moon, M.J. (1999), "The pursuit of managerial entrepreneurship: does organization matter?", Public Administration Review, Vol. 59 No. 1, pp. 31-43.

Noonan, M.C., Estes, S.B. and Glass, J.L. (2007), "Do workplace flexibility policies influence time spent in domestic labor?”, Journal of Family Issues, Vol. 28 No. 2, pp. 263-288.

Nyhan, R.C. (2000), "Changing the paradigm trust and its role in public sector organizations", The American Review of Public Administration, Vol. 30 No. 1, pp. 87-109.

O’Neill, T.A., Hambley, L.A., Greidanus, N.S., MacDonnell, R. and Kline, T.J. (2009), "Predicting teleworker success: an exploration of personality, motivational, situational, and job characteristics", New Technology, Work and Employment, Vol. 24 No. 2, pp. 144-162.

Ordoñez, D.B. (2012), "Sobre subjetividad y (tele) trabajo. Una revisión crítica", Revista de estudios sociales, Vol. 44 No. 44, pp. 181-196.

Osnowitz, D. (2005), "Managing time in domestic space home-based contractors and household work", Gender \& Society, Vol. 19 No. 1, pp. 83-103.

Parker, S.K. and Sprigg, C.A. (1999), "Minimizing strain and maximizing learning: the role of job demands, job control, and proactive personality”, Journal of Applied Psychology, Vol. 84 No. 6, pp. 925-939.

Piskurich, G.M. (1998), An Organizational Guide to Telecommuting: Setting up and Running a Successful Telecommuter Program, American Society for Training and Development, Alexandria, VA.

Pyöriä, P. (2011), "Managing telework: risks, fears and rules", Management Research Review, Vol. 34 No. 4, pp. 386-399.

Shockley, K.M. and Allen, T.D. (2007), "When flexibility helps: another look at the availability of flexible work arrangements and work-family conflict”, Journal of Vocational Behavior, Vol. 71 No. 3, pp. 479-493.

Sullivan, C. (2012), "Remote working and work-life balance", in Michalos, A., Phillips, R., Rahtz, D., Goethe, G., Lee, D. and Camfield, L. (Eds), Work and Quality of Life, Springer, pp. 275-290.

Sullivan, C. and Smithson, J. (2007), "Perspectives of homeworkers and their partners on working flexibility and gender equity", The International Journal of Human Resource Management, Vol. 18 No. 3, pp. 448-461.
Moderators of telework effects 
EJMBE

26,1
Vittersø, J., Akselsen, S., Evjemo, B., Julsrud, T.E., Yttri, B. and Bergvik, S. (2003), "Impacts of home-based telework on quality of life for employees and their partners. quantitative and qualitative results from a European survey", Journal of Happiness Studies, Vol. 4 No. 2, pp. 201-233.

Wiesenfeld, B.M., Raghuram, S. and Garud, R. (1999), "Managers in a virtual context: the experience of self-threat and its effects on virtual work organizations", in Cooper, C.L. and Rousseau, D. (Eds), Trends in Organizational Behavior, Vol. 6, Wiley, pp. 31-44.

\section{Corresponding author}

Martín Solís can be contacted at: marsolis@itcr.ac.cr 